\title{
PENGARUH PEMANASAN TERHADAP KESTABILAN PIGMEN BETALAIN DARI BUAH NAGA MERAH (HYLOCEREUS POLYRHIZUS)
}

\author{
Yelfira Sari \\ Universitas Islam Riau \\ Email: yelfirasari@edu.uir.ac.id
}

\begin{abstract}
Abstrak: Betalain merupakan pigmen alami yang mengandung atom nitrogen dan larut dalam air, terdiri dari campuran betasantin kuning dan betasianin merah. Salah satu sumber penghasil betalain adalah buah naga merah. Ekstrak buah naga merah diukur serapannya pada 200-800 nm menggunakan spektrofotometer UV-Vis. Dari ekstrak buah naga merah, didapatkan dua puncak absorban pada $269 \mathrm{~nm}$ dan $536 \mathrm{~nm}$. Puncak absorban pada $536 \mathrm{~nm}$ ini menunjukkan keberadaan betasianin. Degradasi warna pigmen betalain oleh pengaruh suhu dimonitor dengan spektrofotometer UV-Vis pada $\lambda 536 \mathrm{~nm}$. Hasil penelitian menunjukkan bahwa suhu optimum untuk kestabilan pigmen betalain adalah pada $30^{\circ} \mathrm{C}$.
\end{abstract}

Kata kunci: Hylocereus polyrhizus, betalain, betasianin, spektrofotometer UV-Vis

\section{PENDAHULUAN}

Adanya batasan-batasan terhadap penggunaan zat warna sintetik menyebabkan meningkatnya minat terhadap penelitian tentang zat warna alami. Pewarna alami aman dikonsumsi mengingat hingga saat ini belum ada laporan efek negatifnya pada manusia sehingga pewarna alami menjadi salah satu alternatif bahan pewarna di kalangan masyarakat (Amalia, dkk: 2009).

Beberapa jenis zat warna alami yang sering digunakan sebagai pewarna makanan diantaranya adalah karotenoid, antosianin dan betalain. Pigmen-pigmen tersebut tersebar mulai dari bunga, daun, dan juga akar dari kelompok tanaman buah, sayuran maupun bunga (Amalia, dkk: 2009).

Buah naga merah merupakan salah satu sumber potensial dari berbagai tanaman yang menghasilkan zat warna. Zat warna yang dihasilkan dari buah naga ini berupa pigmen yang disebut dengan pigmen betalain (Rebecca, dkk: 2010).

Betalain merupakan metabolit sekunder berupa pigmen, larut dalam air, mengandung gugus nitrogen dan berperan pada tampilan warna merah-ungu (betasianin) dan kuning-jingga (betasantin) (Rahayu,dkk: -).

Betasianin menunjukkan kandungan pigmen merah-ungu dan terbentuk dari hasil kondensasi dari asam betalamat dengan siklo-DOPA dan memiliki absorbansi pada panjang gelombang antara 534-554 $\mathrm{nm}$. Betasantin menunjukkan pigmen kuning-jingga dan terbentuk dari konjugasi antara asam Betalamat dengan amina atau dengan asam amino dan memiliki absorbansi panjang gelombang antara 470-486 nm (Umayah, Evi dan Moch. Amrun H: 2007).

Ketertarikan industri makanan terhadap betalain sebagai pewarna makanan semakin meningkat ketika dilaporkan mengandung antioksidan alami yang memiliki efek positif terhadap kesehatan manusia, dan menunjukkan aktivitas sebagai anti kanker (Rahayu,dkk: -). 


\title{
METODE PENELITIAN
}

\begin{abstract}
Alat dan Bahan
Alat

Alat yang digunakan adalah seperangkat alat distilasi, seperangkat alat vakum penguap, spektrofotometer UV/Vis (UV-1700 series Shimadzu), termometer, kertas saring, alumunium foil, serta peralatan gelas yang umum digunakan dalam laboratorium.
\end{abstract}

\section{Bahan}

Bahan-bahan yang digunakan adalah daging buah naga merah, etanol, $\mathrm{HCl}$, asam asetat glasial, ammonium asetat, amonia, ammonium klorida, asam sitrat, dinatrium hidrogen pospat, dan akuades.

\section{Ekstraksi Betalain}

Daging buah naga merah dipotong kecil kemudian dihomogenkan dengan etanol. Bubur buah yang diperoleh dimaserasi selama \pm 24 jam, setelah itu disaring dengan kain kasa dan dilanjutkan dengan penyaringan vakum. Filtrat yang diperoleh diuapkan dengan vakum hingga didapatkan ekstrak buah. Ekstrak buah kemudian digunakan untuk analisa selanjutnya.

\section{Analisa Betalain}

\section{Analisa Spektrofotometri}

Ekstrak buah naga merah diukur serapannya dengan spektrofotometer UVVis pada panjang gelombang antara $200-800 \mathrm{~nm}$.

\section{Pengaturan Suhu}

Sampel diberi perlakuan pada 4 suhu berbeda, masing-masing $40^{\circ}, 60^{\circ}$, $80^{\circ}$, dan $100^{\circ} \mathrm{C}$. Masing-masing sampel dipanaskan selama 30 menit, kemudian dimonitor dengan spektrofotrometri UV-Vis pada panjang gelombang 200-800 $\mathrm{nm}$.

\section{Penentuan Degradasi Warna Pigmen Betalain}

Dari perlakuan terhadap pengaruh $\mathrm{pH}$ dan panas diukur absorban masingmasing sampel pada $\lambda_{\max } 536 \mathrm{~nm}$. Persen degradasi warna dapat diketahui dengan persamaan :

$$
\% \text { Degradasi }=\frac{\text { Aawal }- \text { A akhir }}{\text { A awal }} \times 100 \%
$$

Untuk masing-masing sampel diamati perubahan warna yang terjadi. 


\section{HASIL DAN PEMBAHASAN}

\section{Analisa Betalain \\ Analisa Spektrofotometri}

Ekstrak segar dari buah naga merah diukur serapannya pada panjang gelombang 200-800 nm. Spektrum serapan menunjukkan 2 puncak. Puncak pada $536 \mathrm{~nm}$ dan $269 \mathrm{~nm}$ menunjukkan keberadaan betalain (Gambar 1). Berdasarkan spektrum yang diperoleh, dapat dikatakan bahwa betalain yang terkandung dalam buah naga merah ini termasuk ke dalam struktur betasianin karena puncak serapan pada $536 \mathrm{~nm}$ merupakan penyerapan karakteristik untuk kelompok betalain merah-ungu, betasianin [5]. Hal ini sesuai dengan literatur, dimana betalain menunjukkan dua puncak maksimum yaitu pada daerah sinar tampak (534-554 $\mathrm{nm})$ dan daerah UV $(270-280 \mathrm{~nm})$.

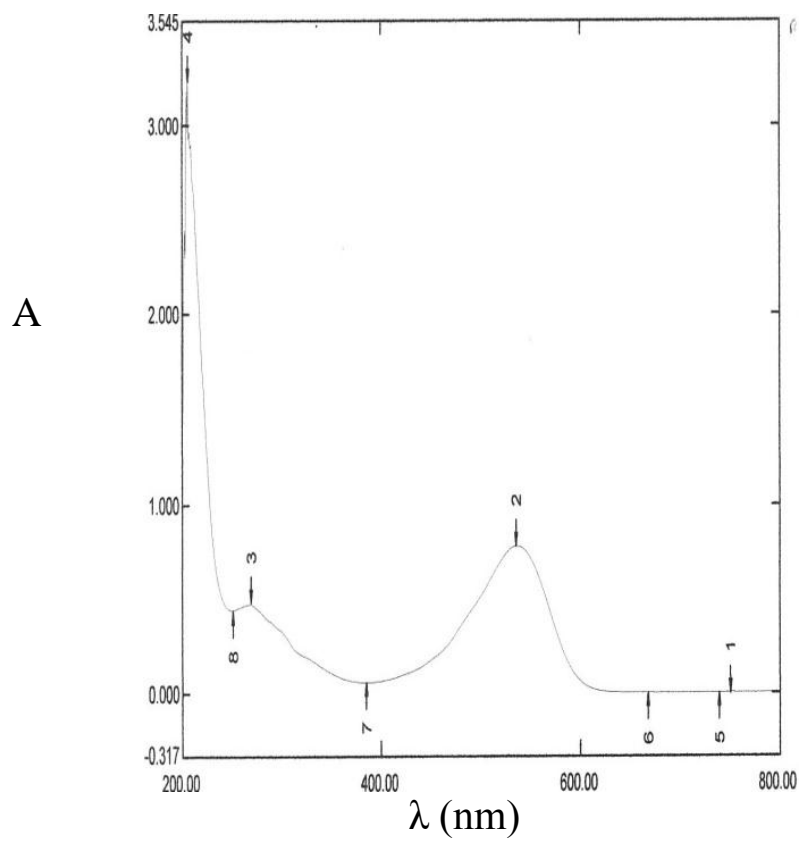

Gambar 1. Spektrum UV-Vis Pigmen Betalain

\section{Pengaruh Pemanasan terhadap Serapan Pigmen Betalain}

Panas merupakan faktor yang sangat penting terhadap kestabilan pigmen betalain. Selama proses pemanasan, kemungkinan terjadi pemutusan ikatan yang menyebabkan terjadi pengurangan warna merah menjadi merah pucat ataupun berubah menjadi kuning terang. Selain oleh panas, perubahan warna ini juga dapat disebabkan oleh basa. Pemutusan ikatan ini akan menghasilkan dua senyawa yaitu asam betalamat (kuning terang) dan siklo-DOPA (tidak berwarna) [6].

Betasianin relatif stabil pada suhu ruang, namun untuk pemanasan hingga suhu $60^{\circ} \mathrm{C}$, tidak menunjukkan perubahan warna yang jelas. Perubahan mulai terjadi pada suhu $80^{\circ} \mathrm{C}$ dan pada suhu $100^{\circ} \mathrm{C}$, warna merah betasianin semakin menghilang. 


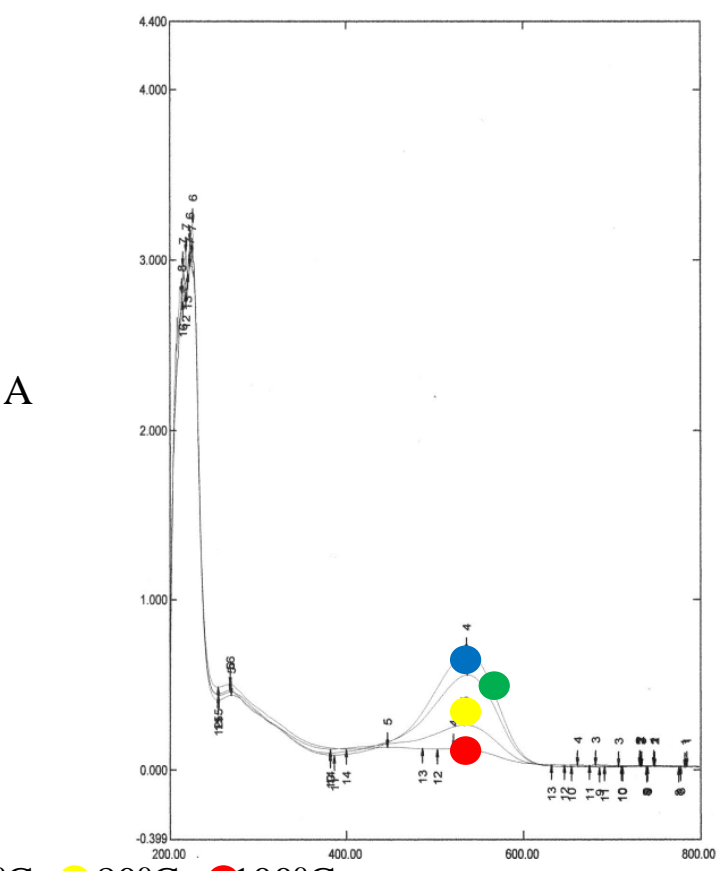

Ket: $40^{\circ} \mathrm{C}, 60^{\circ} \mathrm{C}, 80^{\circ} \mathrm{C}, 900^{\circ} \mathrm{C}$

Gambar 2. Spektrum UV Pigmen Betalain akibat Pengaruh Pemanasan

Selama proses pemanasan, terjadi pengurangan warna merah dari ekstrak buah naga. Hal ini menyebabkan terjadinya penurunan intensitas pada spektrum. Pemanasan hingga suhu $80^{\circ} \mathrm{C}$ tidak menyebabkan terjadinya pergeseran $\lambda_{\max }$, namun pada pemanasan $100^{\circ} \mathrm{C}$ terjadi pergeseran $\lambda_{\max }$ sehingga terbentuk puncak baru pada $521 \mathrm{~nm}$.

\section{Pengaruh Pemanasan terhadap Degradasi Warna Pigmen Betalain}

Pengaruh pemanasan dalam degradasi warna merah pigmen betalain ditunjukkan pada Gambar 3. Pemanasan hingga suhu $100^{\circ} \mathrm{C}$ menyebabkan terjadi degradasi warna hingga $84,23 \%$ sedangkan pada pemanasan suhu $40^{\circ} \mathrm{C}$, degradasi warna hanya terjadi sebesar $11,54 \%$.

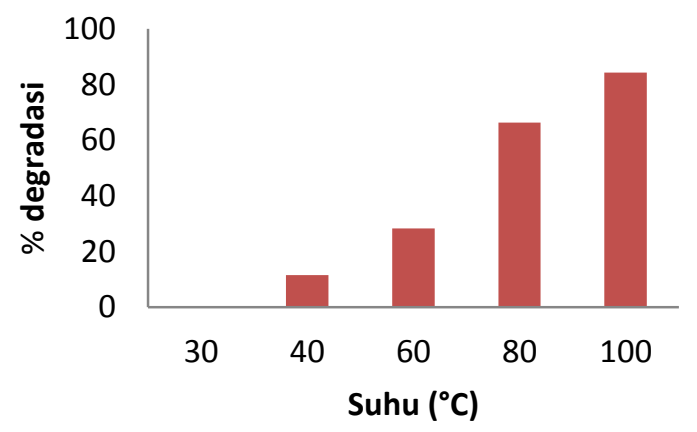

Gambar 3. Degradasi Warna Merah Pigmen Betalain akibat Pengaruh Suhu 
Betalain relatif stabil pada suhu ruang, namun untuk pemanasan hingga suhu $60^{\circ} \mathrm{C}$, tidak menunjukkan perubahan warna. Perubahan mulai terjadi pada suhu $80^{\circ} \mathrm{C}$ dan pada suhu $100^{\circ} \mathrm{C}$, warna merah betanin semakin menghilang.

Langkah pertama dari degradasi pigmen betalain oleh suhu adalah pengaruh hidrolisis oleh air pada senyawa betasianin. Langkah ini menghasilkan siklo-DOPA-5-O- $\beta$-glukosida dan asam betalamat. Senyawa ini dapat mengalami regenerasi pada suhu rendah, namun pada suhu yang tinggi regenerasi tidak dapat terjadi karena asam betalamat tidak tahan terhadap pemanasan.

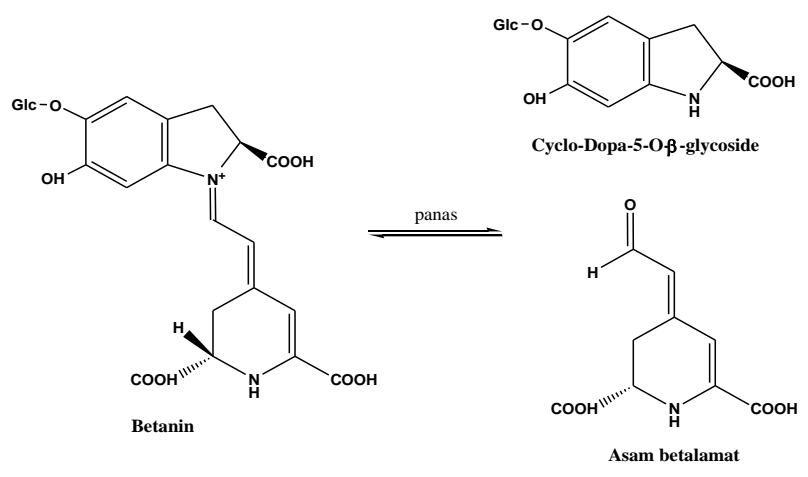

Gambar 4. Reaksi pemutusan ikatan senyawa betasianin pada suhu tinggi

\section{KESIMPULAN}

Dari penelitian yang telah dilakukan, dapat disimpulkan bahwa pigmen betalain relative tidak stabil terhadap pemanasan, dimana semakin tinggi suhu yang diberikan, warna pigme akan semakin berkurang. Suhu optimum dari pigmen betalain ini adalah pada suhu ruang $\left( \pm 30^{\circ} \mathrm{C}\right)$.

\section{DAFTAR RUJUKAN}

Amalia, Indrian R., Aziza Slyvia H., dan Dian S., Studi efektivitas penggunaan ekstrak pigmen bunga bugenvil (Bougainvillea spectabilis) sebagai zat warna alami pada produk jajanan pasar, Jurusan Biologi, Fakultas Matematika dan Ilmu Pengetahuan Alam, Universitas Brawijaya, Malang, Indonesia, (2009).

Rebecca, O.P.S., A.N. Boyce, and S. Chandran, Pigment identification and antioxidant properties of red dragon fruit (Hylocereus polyrhizus), African Journal of Biotechnology., 9, (2010), 1450-1454.

Rahayu, Dwi P., Retno Mastuti, Anna Roosdiana. Kultur kalus sebagai penghasil betalain secara in Vitro. Fakultas Matematika dan Ilmu Pengetahuan Alam, Universitas Brawijaya, Malang, Indonesia.

Umayah, Evi dan Moch. Amrun H. Uji aktivitas antioksidan ekstrak buah naga (Hylocereus undatus (Haw.)) Britt. \& Rose. Jurnal Ilmu Dasar., 8, (2007), 83-90. 
Woo, K. K., F. H. Ngou, L. S. Ngo, W. K. Soong and P. Y. Tang. Stability of betalain pigmen from red dragon fruit (Hylocereus polyrhizus). American Journal of Food Technology., 6, (2011), 140-148.

Azeredo, Henriette M.C., Betalains: properties, sources, applications, and stability-a review, International Journal of Food Science and Technology, 44, (2009), 2365-2376. 